\title{
Effect of processing on physico-chemical and functional properties of flours from cluster or guar bean (Cyamopsis tetragonoloba) varieties
}

\author{
Priyanka Sharma ${ }^{*}$, Amarjeet Kaur ${ }^{1}$ and M. S. Alam ${ }^{2}$ \\ Department of Food Science and Technology, Punjab Agricultural University, Ludhiana-141004 (Punjab), INDIA \\ Department of Processing and Food Engineering, Punjab Agricultural University, Ludhiana-141004 (Punjab), INDIA \\ *Corresponding author. E-mail: priyankasharma859@gmail.com
}

Received: March 23, 2016; Revised received: August 27, 2016; Accepted: November 15, 2016

\begin{abstract}
Guar bean (Cyamopsis tetragonoloba) offers a potential source of vegetable protein and fibre, however, its utilization in food is yet to be explored. Along with the nutritional value, its effect on other properties of food is inevitable. Thus, the present study was carried to study the physicochemical and functional properties (water absorption index, water solubility index, foaming capacity, foaming stability, oil absoption capacity and gelling strength) of flours from different varieties of guar bean (i.e. G 80, Ageta 112 and HG 365) and related to each other using Pearson correlation. Significant variations were observed in the chemical composition of flour from varieties of guar bean on processing. Germination of seeds increased the protein significantly and highest levels of increased protein content were observed in G $80(+21.6 \%)$. Dehusking significantly increased (upto $5.9 \%$ ) and extrusion processing reduced (upto $23.6 \%$ ) the $L^{*}$ value significantly in flours from guar bean varieties. Germination increased while extrusion processing reduced the WAI and WSI. Dehusking, autoclaving and germination were observed to increase the foaming capacity significantly; however, extrusion processing markedly reduced the foaming properties of guar flours. Extrusion processing immensely affected the gelling properties of flour from guar bean varieties and lead to loss of gel formation properties. Pearson's correlation determined a significant correlation between processing treatments and functional properties.
\end{abstract}

Keywords: Autoclaving, Extrusion, Functional properties, Germination, Guar bean

\section{INTRODUCTION}

Cluster bean or guar bean (Cyamopsis tetragonoloba) is a drought resistant annual pod bearing crop belonging to the family Leguminaceae and sub family paplionaceae. The crop is majorly produced in India (7-8 lakh tonnes) (Singh and Kheterpaul, 2011) and Pakistan and bears the potential to be utilized as low cost plant origin protein source. The crop offers protein enriched diets for malnourished population of developing countries, including India. Guar bean, which finds maximum consumption for fodder and gum extraction purposes, contains $24.5-34.0 \%$ protein, 3.1-7.5\% lipid, and 35-45\% carbohydrate (Joshi et al., 1990). Incorporation of legumes is also expected to enhance the fibre content in food that helps in lowering the risk of cancer, bowel diseases, osteoporosis (Strtori and Lovati 2001). Works of various authors have shown good health effects of guar gum like antihyperlipidemic (Fabrenbach, 1965), antidiabetic (Brennan et al., 1995). Guar gum has been studied as a substitute for fat in human food to decrease total caloric content (Zambrano et al., 2004). Addition of legume to food products affects its final characteristics due to its functional properties. However, the low consumption of guar bean for food purposes has been attributed partly to its presence of anti-nutritional factors (viz. tannins, polyphenols etc.) and its beany flavour. Thus, processing of seeds is necessary for its safe consumption. Processing of seeds shows altercation in functional properties. Various treatments are used for reducing the antinutritional content like dehulling, roasting, germination, boiling, cooking, microwave etc. In order to utilize the potential of guar bean in food, it is mandatory to study its properties as affected by processing treatments. Thus in present study, the guar varieties were processed and its effect on the physico- chemical and functional properties were studied.

\section{MATERIALS AND METHODS}

Raw materials: Three varieties of Cyamopsis tetragonoloba i.e. G 80, Ageta 112 and HG 365 were obtained from Punjab Agricultural University, Ludhiana. The seeds were cleaned manually to remove damaged seeds and other foreign materials. The cleaned seeds were then stored in polyethylene bags for further use. All chemicals used were of analytical grade.

Processing of seeds: The guar seeds were subjected to various treatments in order to reduce the anti nutritional factors viz. dehusking, soaking, autoclaving, extrusion processing and germination.

Dehusking: The guar seeds of all the three varieties 
were roasted for $2 \mathrm{~min}$ and the outer layer of seeds were removed using the barley pearler for $2 \mathrm{~min}$. The splits obtained were separated from the husk and ground in Cyclotech mill (Foss, Denmark). The particle size of flour was enough to pass through $200 \mu$ mesh sieve. The flour was stored in polypropylene bags for further studies.

Soaking: The time and temperature conditions were finalized for soaking on the basis of literature. $100 \mathrm{~g}$ of seeds of each variety were kept in water at room temperature $\left(27-30{ }^{\circ} \mathrm{C}\right)$ for 18 hours. The water was drained and the steeping losses during soaking of seeds were determined. Treated seeds were dried at $50{ }^{\circ} \mathrm{C}$ followed by grinding of seeds in Cyclotech mill (Foss, Denmark). The particle size of flour was enough to pass through $200 \mu$ mesh sieve. The flour was stored in polypropylene bags for further studies.

Autoclaving: The seeds were pressure cooked in an autoclave at a temperature of $110{ }^{\circ} \mathrm{C}$ for $10 \mathrm{~min}$ at 120 psi. The treated guar seeds were then dried at $60{ }^{\circ} \mathrm{C}$ and ground to flour and stored in polypropylene bags for further use and studies.

Extrusion processing: The seeds of guar variety were milled in Cyclotech mill (Foss, Denmark) to a particle size to pass through $200 \mu$ mesh sieve. Flour obtained were subjected to extrusion processing using Clextral BC 21 (Clextral, Firminy, France), co-rotating intermeshing twin screw extruder having $400 \mathrm{~mm}$ useful length and $2.5 \mathrm{~mm}$ screw diameter and was equipped with a single screw volumetric feeder. Barrel temperature was set at $25^{\circ} \mathrm{C}, 75^{\circ} \mathrm{C}, 100^{\circ} \mathrm{C}$ and $170^{\circ} \mathrm{C}$ for $1^{\text {st }}$, $2^{\text {nd }}, 3^{\text {rd }}$ and $4^{\text {th }}$ zones respectively. Screw speed was maintained at $500 \mathrm{rpm}$. Moisture content of samples was adjusted to $17 \%$. Feeder speed was set to feed at $20 \mathrm{Kg} / \mathrm{h}$. The die was fitted with one circular insert having $3 \mathrm{~mm}$ diameter. The resultant product was cooled, ground to prepare it in flour form followed by packing in polypropylene bags.

Germination: Guar seeds were sterilized by soaking in ethanol for $1 \mathrm{~min}$. The seeds were soaked in distilled water $(1: 10, \mathrm{w} / \mathrm{v})$ at $30 \pm 5^{\circ} \mathrm{C}$ for 8 hours, then kept between thick layers of muslin cloth and allowed to germinate in the dark for 3 days. The germinated seeds were then dried at $50{ }^{\circ} \mathrm{C}$ followed by grinding of seeds. The particle size of flour was enough to pass through $200 \mu$ mesh sieve. The flour was stored in polypropylene bags for further studies.

Preparation of samples: The treated dried legume samples were milled in Cemotech Mill (Model- 3303 Perten, Finland) to flour fineness and stored in labeled high density polyethylene bags for subsequent use in analysis.

Chemical composition: Physico-chemical characteristics such as moisture, crude protein, crude fat, fibre and ash of raw and processed guar bean were determined using AACC ( 2000 ) methods (American Association of Cereal Chemists). The conversion factor used for calculating the protein content was 6.5. Total carbohydrate content was determined by the difference.
Colour analysis: Colour analysis was performed using Hunter Lab Colorimeter, Minolta. Colour readings were expressed by Hunter values for $L^{*}, a^{*}$ and $b^{*}$. The $\mathrm{a}^{*}$ value ranges from -100 (greenness) to +100 (redness), the $b^{*}$ value ranges from -100 (blueness) to +100 (yellowness), whereas the $L^{*}$ value, indicating the measure of lightness, ranges from 0 (black) to 100 (white) (Hutchings, 1999). Chroma and hue angle were calculated using the formulas below (Eq. $i$ and ii).

$$
\begin{array}{ll}
\text { Chroma }\left(C^{8}\right)=\sqrt{a^{2}+b^{2}} & \text { (Eq.i) } \\
\text { Hue Angle }\left(C^{\circ}\right)=\tan ^{-1}\left(\frac{b}{a}\right) & \text { (Eq.ii) }
\end{array}
$$

\section{Functional properties}

Water absorption capacity (WAC): Suspension was prepared by adding $10 \mathrm{ml}$ of distilled water to $1 \mathrm{~g}$ of treated guar flour and stirred for $5 \mathrm{~min}$ in centrifuge tubes. The tubes were then centrifuged at $3000 \mathrm{~g}$ for 30 min and the supernatant was collected in evaporating dish. Weight of solids obtained after evaporating the supernatant was used to calculate water absorbtion index (Eq. iii) and water solubility index (Eq. iv) was determined by the water absorbed by the sediments (Adebowale et al., 2005, Kaur et al., 2007).

Foaming properties: A suspension was prepared by adding a known weight of sample to $100 \mathrm{ml}$ of distilled water. The suspension was homogenized for $5 \mathrm{~min}$. The mixture was poured immediately into a $250 \mathrm{~mL}$ measuring cylinder and the volume was recorded after $30 \mathrm{~s}$. Foam capacity (FC) was expressed as \% increase in volume (Khattab and Arntfield, 2009) by the formula (Eq. v):

$$
\begin{gathered}
W A I(g / g)=\frac{\text { Weight of sediment }}{\text { Weight of dry solids }} \quad \text { (Eq. iii) } \\
\text { WSI }(\%)=\frac{\text { Weight of dissolved solid in supernatant }}{\text { Weight of dry solids }} \times 100 \quad \text { (Eq.iv) }
\end{gathered}
$$

The change in volume of foam after 60 minutes of standing at room temperature was recorded as foam stability (Eq. vi).

Oil absorption capacity (OAC): OAC was determined according to Adebowale et al. (2005). One gram of the meal was mixed with $10 \mathrm{~mL}$ oil in a centrifuge tube and allowed to stand at room temperature for $1 \mathrm{~h}$ followed by centrifugation at 3000 for $30 \mathrm{~min}$. The difference in the initial volume of oil added to the sample and the volume of the supernatant was measured to determine oil absorption capacity as milliliters of oil absorbed per gram of sample.

Foaming Capacity $\%=\frac{\text { (Vol. after whipping }- \text { Vol. before whipping) }}{\text { (vol, before whipping) }} \times 100$ (Eq. v)

Gel formation: Gelation was investigated according to Adebowale et al. (2005). Suspensions of 2-20 g sample/100 $\mathrm{mL}$ distilled water were prepared. Ten $\mathrm{mL}$ of each dispersion was transferred into a test tube. It was 
heated in a boiling water bath for $1 \mathrm{~h}$, followed by rapid cooling in a cold water bath. The tubes were further cooled at $4{ }^{\circ} \mathrm{C}$ for $2 \mathrm{~h}$. The least gel concentration was determined as the concentration when the sample from the inverted test tube did not slip or fall.

Foaming Stability $\%=\frac{(\text { Foam volume after time } t)}{\text { (Initial foam volume })} \times 100$

Statistical analysis: The statistical procedures were performed using SPSS (version 16.0) SPSS Inc (Chicago, USA). A comparison of the means was ascertained by Tukey's test, to $5 \%$ level of significance using an analysis of the variance (ANOVA). Pearson's correlation was calculated to study the relationship among various properties.

\section{RESULTS AND DISCUSSION}

Proximate composition: Chemical compositions of raw and treated guar bean seeds revealed significant increase in protein content on germination in G 80 $(+21.55 \%)$, Ageta $112(+15.87 \%)$ and HG 365 $(+17.40 \%)$ as depicted in Fig. 1. The increase in protein content on germination was possibly due to degradation of high molecules of the protein to simple peptides during germination process and use of other components in the seeds during the germination process (Khalil and Mansour 1995, Mubarak 2005). Rumiyati et al. (2012) observed gradual increase of $38 \%$ in protein content of lupin seeds during germination study of 9 days. Similar trend was observed by El-Adawy (2002) for chickpea. Removal of hull increased the protein content for all three varieties i.e. G 80, Ageta 112 and HG 365. Mugendi et al. (2010) observed the similar results from study for mucuna beans where increase in protein was noted after dehulling of seeds. Increase during high temperature treatments might be because of the high digestibility of proteins during processing (Mittal et al., 2012).

Processing of seeds showed no significant variation in fat content; however, germination of seeds slightly reduced the fat percent. The decrease in this fraction was due to consumption of energy for germination of seeds. El-Adawy (2002) reported decrease in fat on treatments i.e. autoclaving, boiling, germination to chickpea. Significant decrease in fat of germinated mung bean was observed by Mubarak (2005). Esenwah and Ikenebomeh (2008) reported increase in fat content on soaking and boiling of African locust bean seed. The increase was stated due to cleavage of carbohydrate-lipid complex and protein - lipid complex, facilitating the extraction of oil. However, the findings were contrary to those observed in our study. The increase might be possibly due to formation of proteinfibre complex (Mittal et al., 2012). Rumiyati et al. (2012) reported a gradual decrease in fat content and increase in fibre during the germination of Australian sweet lupin. Similar trend was observed in our study where an increased fibre fraction was observed on germination. Maximum increase of $45 \%$ was observed in fibre content of Ageta $112(12.24 \pm 0.34 \%)$, followed by HG $365(13.43 \pm 0.20 \%)$ and G $80(12.16 \pm 0.27$ $\%)$. El-Adawy (2002) showed increase of $36.39 \%$ in fibre on germination of chickpea. However, a different trend was reported by Mubarak (2005) with a slight decrease in fibre content in mung bean seeds. Autoclaving and extrusion processing marked no significant difference on fibre content in guar seeds. This increase in dietary fibre could be due to changes in the polysaccharides found in the cell wall such as cellulose, glucose and mannose, suggesting that the changes were due to an increase in the cellular structure of the plant during germination (Martin-Cabrejas et al., 2003, Rumiyati et al., 2012). The crude fibre content during germination American sweet lupin was increased by $456 \%$ after 9 days (Rumiyati et al., 2012). An increase of $36 \%$ in dietary fibre was reported in L. albus following germination for 2 days (Trugo et al., 2000). The effect of germination on dietary fibre of peas was evaluated by Martin-Cabrejas et al, (2003) and a substantial increase was found in total dietary fibre.

Ash content showed no significant difference in processed guar seeds, however, Mugendi et al. (2010) during study on mucuna beans reported a considerable decrease in ash content on dehulling from 3.53 to 0.30 $\mathrm{g} / 100 \mathrm{~g}$. Studies of El-Adawy (2002) on chickpea concluded no significant variation in ash content on processing. Dehusked and soaked guar seeds showed maximum carbohydrate content for all three varieties. Reduction in proportion of fibre was responsible for increased endosperm portion. HG 365 revealed maximum rise in carbohydrate content in processed seeds. Although no such rise was observed in autoclaved chickpea seeds however, germination reduced carbohydrates as was observed in present study. Faba beans studies by Khalil and Mansour (1995) reported reduction from $44.1 \mathrm{~g} / 100 \mathrm{~g}$ to $41.1 \mathrm{~g} / 100 \mathrm{~g}$ on germination, however, an increase was observed in autoclaved seeds.

Colour analysis: The Hunter color values ( $\left.L^{*}, a^{*}, b^{*}\right)$ of the raw and treated guar seed flours was performed and the results have been presented in Table 1. Among the raw guar seed flours studied, highest $\mathrm{L}^{*}$ value was observed for Ageta $112(79.26 \pm 0.52)$, indicating the flour's lighter color, followed by HG 365 (76.97 \pm 0.62$)$ and $G 80$ (76.51 \pm 0.71$)$. Processing of guar seeds significantly affected its $L^{*}$ value for all the varieties. An increase in $\mathrm{L}^{*}$ value was observed on dehulling, whereas other treatments reduced the value. Removal of outer seed coat on dehulling was responsible for the light colour of flour. Darkest coloured flours were obtained from extrusion treatment. HG 365 however showed an increased L* value on soaking and autoclaving.

All the flours showed negative $a^{*}$ values, indicating the greenness of flours and varied significantly on processing. The a* value signifies the greenness and was 
G 80

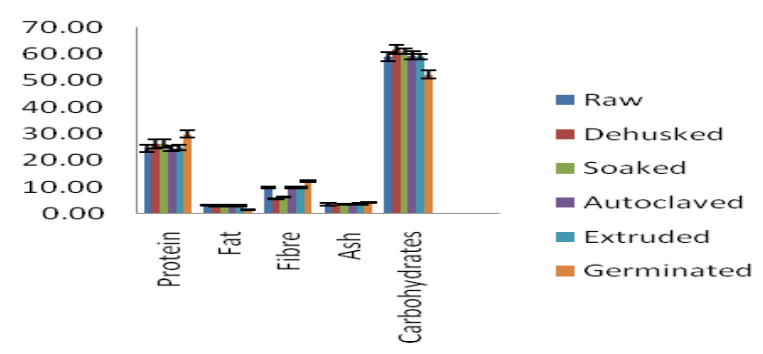

Ageta 112
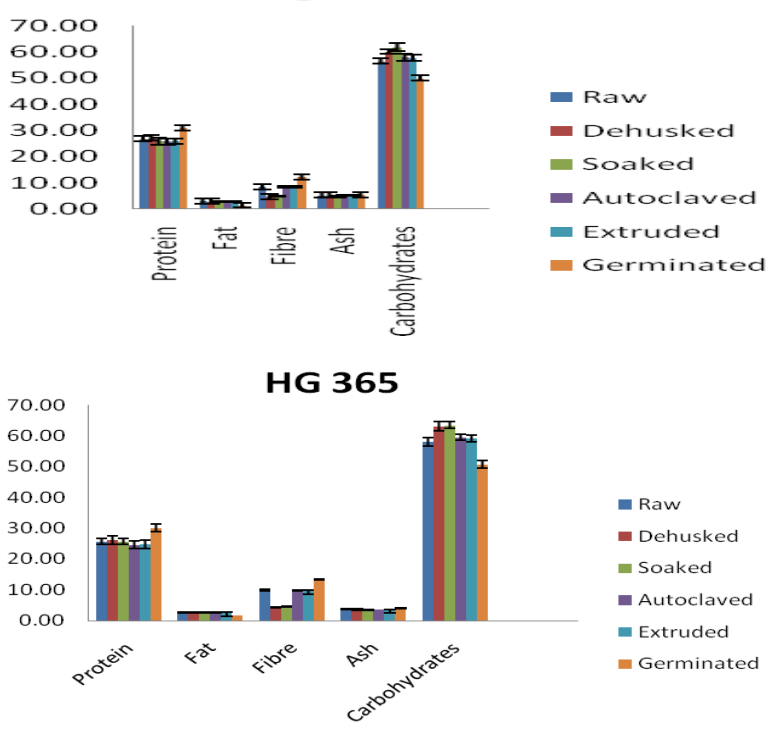

Fig. 1. Proximate composition of processed flour form guar varieties a) G 80 b) Ageta 112 c) HG 365.

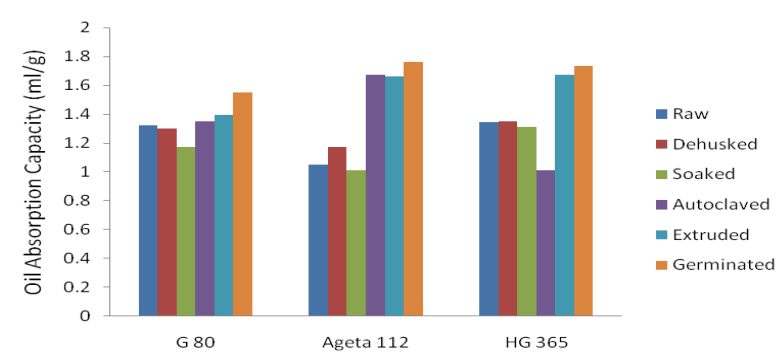

Fig. 2. Effect of processing on oil absorption capacity of flours from guar varieties.

estimated to be highest for Ageta $112(-2.68 \pm 0.17)$ varied significantly from HG $365(-2.07 \pm 0.01)$ and $G$ $80(-2.03 \pm 0.02)$. The seed coat of guar seed contributed to the $\mathrm{a}^{*}$ value, thus dehulling of seeds reduced the greenness. Significant variation was observed in $\mathrm{a}^{*}$ value of guar seed flours on treatments, however, no definite trend was observed in $a^{*}$ value of flour obtained from treated guar seeds. The positive $b^{*}$ values of guar seed flours depicts the yellowness of flour and was recorded highest for HG 365 (9.20 0.21$)$, followed by Ageta $112(9.06 \pm 0.01)$ and $G \quad 80$

\section{Gel strength (\%)}

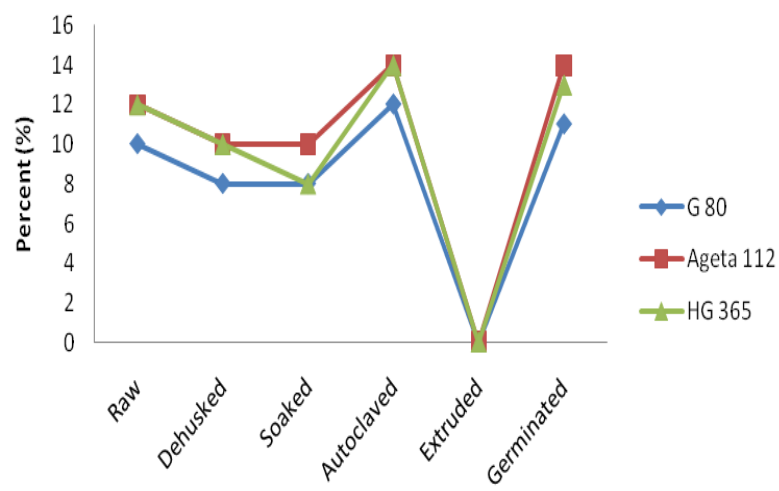

Fig .3. Effect of processing on gel strength of flours from guar varieties.

$(8.96 \pm 0.14)$. Treatment of seeds exhibited significant variation in $b^{*}$ value in guar seed varieties. Dehulling, autoclaving, extrusion and germination increased the $b^{*}$ value, however, soaking of guar seed significantly reduced $b^{*}$ value. Soaking decreased the $b^{*}$ value, whereas, extrusion process increased the $b^{*}$ values.

Among the raw guar seed varieties, Ageta 112 exhibited highest. Chroma depicted a similar trend as was observed for $b^{*}$ value that could be explained due to direct proportionality of chroma and $b^{*}$ value. Extruded seed flour was recorded with highest chroma and minimum chroma value was assessed in soaked guar seeds. Autoclaving of seeds increased the $b^{*}$ and chroma value however, the effect was less than that of extrusion.

Hue angle of guar varieties were $103.8^{\circ}, 106.5^{\circ}$ and $102.7^{0}$ respectively for G 80, Ageta 112 and HG 365 . Treatment of seeds made significant variation in hue angle of guar varieties. G 80 soaked guar seeds revealed maximum hue angle for guar varieties. Otherwise no definite trend could be recorded for treatment of seeds on hue angle.

Functional properties: Processing of seeds showed marked effects on the functional properties i.e. water binding, solubility, foaming, gelling and fat binding properties. Functional properties are significantly correlated in determining the final quality and acceptance of the product.

Water absorption properties: Guar variety G 80 showed slight increase on processing, except, extrusion processing, however variation was non significant (Table 2). Ageta 112 and HG 365 showed significant variation on processing. Germination of seeds increased WAI and highest increase was observed in HG 365 (+26.78\%). G 80 showed maximum water solubility index among all three varieties and varied significantly on processing. Processing of seeds decreased WSI, except for soaking, where an increase was observed. Extruded seeds flour showed minimum water 
Table 1. Effect of processing on colour of flours from guar varieties.

\begin{tabular}{|c|c|c|c|c|c|}
\hline Treatment & $\mathbf{L}^{*}$ & $\mathbf{a}^{*}$ & $\mathbf{b}^{*}$ & Chroma & Hue angle $\left({ }^{\circ}\right)$ \\
\hline \multicolumn{6}{|c|}{ Colour of flours from treated G 80 variety } \\
\hline Raw & $76.51^{b} \pm 0.71$ & $-2.03^{\mathrm{b}} \pm 0.02$ & $8.96^{\mathrm{e}} \pm 0.14$ & $9.19^{\mathrm{e}} \pm 0.13$ & $103.8^{\mathrm{b}} \pm 0.25$ \\
\hline Dehusked & $80.99^{\mathrm{a}} \pm 0.29$ & $-2.59^{c} \pm 0.07$ & $11.44^{\mathrm{c}} \pm 0.11$ & $11.73^{\mathrm{c}} \pm 0.11$ & $102.8^{\mathrm{a}} \pm 0.15$ \\
\hline Soaked & $74.33^{\mathrm{b}} \pm 0.41$ & $-2.58^{\mathrm{c}} \pm 0.04$ & $8.03^{\mathrm{f}} \pm 0.08$ & $8.44^{\mathrm{f}} \pm 0.09$ & $107.8^{\mathrm{b}} \pm 0.12$ \\
\hline Autoclaved & $75.42^{\mathrm{b}} \pm 0.85$ & $-1.77^{\mathrm{a}} \pm 0.10$ & $9.92^{\mathrm{d}} \pm 0.12$ & $10.08^{\mathrm{d}} \pm 0.13$ & $100.1^{\mathrm{b}} \pm 0.53$ \\
\hline Extruded & $58.99^{\mathrm{c}} \pm 0.37$ & $-3.15^{\mathrm{d}} \pm 0.07$ & $14.64^{\mathrm{a}} \pm 0.01$ & $14.97^{\mathrm{a}} \pm 0.01$ & $102.1^{\mathrm{c}} \pm 0.26$ \\
\hline Germinated & $75.34^{\mathrm{b}} \pm 1.02$ & $-2.62^{\mathrm{c}} \pm 0.17$ & $12.05^{\mathrm{b}} \pm 0.26$ & $12.34^{\mathrm{b}} \pm 0.36$ & $102.3^{\mathrm{a}} \pm 0.56$ \\
\hline \multicolumn{6}{|c|}{ Colour of flours from treated Ageta 112 variety } \\
\hline Raw & $79.26^{b} \pm 0.52$ & $-2.68^{\mathrm{b}} \pm 0.17$ & $9.06^{\mathrm{d}} \pm 0.01$ & $9.45^{\mathrm{c}} \pm 0.05$ & $106.5^{\mathrm{b}} \pm 0.91$ \\
\hline Dehusked & $82.87^{\mathrm{a}} \pm 0.88$ & $-2.65^{\mathrm{b}} \pm 0.05$ & $12.95^{\mathrm{b}} \pm 0.09$ & $13.22^{\mathrm{a}} \pm 0.10$ & $101.5^{\mathfrak{c}} \pm 0.15$ \\
\hline Soaked & $77.97^{\mathrm{bc}} \pm 0.52$ & $-2.63^{\mathrm{b}} \pm 0.07$ & $8.09^{\mathrm{e}} \pm 0.01$ & $8.50^{\mathrm{d}} \pm 0.02$ & $106.6^{\mathrm{a}} \pm 0.46$ \\
\hline Autoclaved & $77.14^{\mathrm{c}} \pm 0.65$ & $-2.07^{\mathrm{a}} \pm 0.01$ & $11.42^{\mathrm{c}} \pm 0.16$ & $11.72^{\mathrm{b}} \pm 0.15$ & $103.0^{\mathrm{c}} \pm 0.40$ \\
\hline Extruded & $61.95^{\mathrm{d}} \pm 0.13$ & $-2.63^{\mathrm{b}} \pm 0.06$ & $13.63^{\mathrm{a}} \pm 0.02$ & $13.79^{\mathrm{a}} \pm 0.02$ & $98.7^{\mathrm{d}} \pm 0.06$ \\
\hline Germinated & $78.12^{\mathrm{b}} \pm 0.85$ & $-2.55^{\mathrm{c}} \pm 0.15$ & $13.11^{\mathrm{ab}} \pm 0.54$ & $13.38^{\mathrm{a}} \pm 0.57$ & $101.6^{\mathrm{c}} \pm 0.57$ \\
\hline \multicolumn{6}{|c|}{ Colour of flours from treated HG 365 variety } \\
\hline Raw & $76.97^{\mathrm{c}} \pm 0.62$ & $-2.07^{\mathrm{a}} \pm 0.01$ & $9.20^{\mathrm{c}} \pm 0.21$ & $9.43^{\mathrm{d}} \pm 0.20$ & $102.7^{\mathrm{c}} \pm 0.25$ \\
\hline Dehusked & $80.84^{\mathrm{a}} \pm 0.51$ & $-2.38^{\mathrm{b}} \pm 0.10$ & $11.03^{\mathrm{a}} \pm 0.15$ & $11.28^{\mathrm{c}} \pm 0.13$ & $102.2^{\mathrm{c}} \pm 0.62$ \\
\hline Soaked & $77.26^{\mathrm{c}} \pm 0.12$ & $-2.64^{c} \pm 0.07$ & $7.21^{\mathrm{d}} \pm 0.03$ & $7.68^{\mathrm{e}} \pm 0.04$ & $110.1^{\mathrm{a}} \pm 0.45$ \\
\hline Autoclaved & $79.22^{\mathrm{ab}} \pm 0.32$ & $-2.63^{b c} \pm 0.07$ & $9.40^{\mathrm{b}} \pm 0.01$ & $9.76^{\mathrm{d}} \pm 0.02$ & $105.7^{\mathrm{b}} \pm 0.38$ \\
\hline Extruded & $58.78^{\mathrm{d}_{ \pm}} \pm 0.12$ & $2.56^{\mathrm{bc}} \pm 0.14$ & $13.76^{\mathrm{a}} \pm 0.11$ & $13.99^{\mathrm{a}} \pm 0.09$ & $100.5^{\mathrm{d}} \pm 0.60$ \\
\hline Germinated & $77.41^{\mathrm{c}} \pm 1.30$ & $-2.44^{b c} \pm 0.12$ & $11.89^{\mathrm{a}} \pm 0.64$ & $12.14^{\mathrm{b}} \pm 0.71$ & $101.6^{\mathrm{cd}} \pm 0.55$ \\
\hline
\end{tabular}

${ }^{*}$ Means of triplicate analysis; ${ }^{* *}$ Means followed by same letter within a column do not differ significantly $(\mathrm{P} \leq 0.05)$.

solubility index, however, results reported by Alonso et al. (2000) stated significant increase of WAC and WSI of extrudates in both peas and kidney beans. Dehusking, autoclaving and germination of seeds increased WAI and decreased WSI for all three varieties. The results are supported by the findings of Nagmani and Prakash, 1997 in lentil flour, Ma et al. (2011) for various varieties of lentil and chickpea. The denaturation of proteins on heating improves the waterimbibing capacity due to greater porosity, better fluid entrapment and greater water binding properties by amino acid residues exposed as a result of denaturation (Lin et al., 1974). In addition, starch gelatinization and the swelling of crude fiber during heating might also contribute to increase WAC (Aguilera et al., 2009). Flours with higher water binding properties show better handling characteristics and are thus desirable in bakery formulation (Wolf, 1970).

Foaming properties: Foaming characteristics are dependent on formation and sustainability of interfacial films formed by proteins between the air and liquid phase. Foaming properties are dependent on the proteins as well as on other components such as carbohydrates. Higher air incorporation leads to better foaming capacity and slower rate of coalescence of air bubbles measures its foaming stability (Ma et al., 2011). Guar bean flour showed good foaming properties that may be attributed to its protein content and the galactoman- nans present. Dehusking was observed to significantly improve the foaming capacity and stability of guar varieties (Table 2). This significant rise of foaming properties may be contribution of increased galactomannan content in dehusked seed flour. Dehusked Ageta 112 showed highest foaming capacity of all treated guar seed flours. Extrusion processing however markedly lowered the foaming properties of guar seed flours. Ghavidel and Prakash (2006) concluded that dehulling and germination increased the foaming capacity and decreased foaming stability. However, findings of our research concludes increase in both foaming capacity as well as stability, although, increase in latter is lesser than the former. Denaturation of proteins and gums present in guar seed flour might result in increased viscosity, which might impart rigidity to the interfacial film for foam stabilization of flours (Ma et al., 2011).

Oil absorption capacity: The oil absorption capacity $(\mathrm{OAC})$ is an important functional property and contributes to the mouthfeel and the retention of flavor (Ma et al., 2011). The OAC of flours ranged from 1.01 to 1.76 $\mathrm{ml} / \mathrm{g}$. Germination of seeds raised the OAC to maximum extent that was possibly due to increased protein content in germinated seeds. Ghavidel and Prakash (2006) reported an increased fat absorption capacity in germinated green gram, lentil, cowpea and Bengal gram. The oil absorption capacity is dependent on the non-polar side chains of the protein as well as to the 
Table 2. Effect of processing on Water absorption properties of flours from guar varieties.

\begin{tabular}{|c|c|c|c|c|c|c|}
\hline \multicolumn{7}{|c|}{ WAI (g/g) } \\
\hline Variety & Raw & Dehusked & Soaked & Autoclaved & Extruded & Germinated \\
\hline G 80 & $5.41^{\mathrm{ay}} \pm 0.47$ & $6.53^{\mathrm{axy}} \pm 0.48$ & $6.58^{\mathrm{ax}} \pm 0.58$ & $6.31^{\mathrm{ax}} \pm 0.35$ & $5.38^{\mathrm{ax}} \pm 0.49$ & $6.72^{\mathrm{ax}} \pm 0.33$ \\
\hline Ageta 112 & $5.92^{b x} \pm 0.61$ & $6.91^{\mathrm{ax}} \pm 0.45$ & $6.45^{\text {abxy }} \pm 0.55$ & $6.39^{\mathrm{abx}} \pm 0.62$ & $5.94^{\mathrm{bx}} \pm 0.37$ & $6.94^{\mathrm{ax}} \pm 0.56$ \\
\hline HG 365 & $5.34^{\text {by }_{ \pm}} \pm 0.53$ & $5.77^{\mathrm{abz}} \pm 0.35$ & $\begin{array}{c}5.58^{\mathrm{abz}} \pm 0.38 \\
\text { WSI (\%) }\end{array}$ & $6.60^{\mathrm{ax}} \pm 0.46$ & $5.19^{\mathrm{bx}} \pm 0.31$ & $6.77^{\mathrm{ax}} \pm 0.44$ \\
\hline G 80 & $10.26^{\mathrm{ax}} \pm 0.50$ & $8.53^{\text {by }} \pm 0.42$ & $10.05^{\mathrm{ay}} \pm 0.54$ & $8.42^{\mathrm{by}_{ \pm}} \pm .42$ & $3.02^{\mathrm{cz}} \pm 0.50$ & $7.65^{\text {by }} \pm 0.34$ \\
\hline Ageta 112 & $9.51^{\mathrm{bx}} \pm 0.35$ & $9.04^{\text {by }} \pm 0.11$ & $11.35^{\mathrm{axy}_{ \pm}} \pm 0.71$ & $6.29^{\mathrm{cdz}} \pm 0.24$ & $7.16^{\mathrm{cx}} \pm 0.21$ & $6.05^{\mathrm{dz}} \pm .32$ \\
\hline HG 365 & $8.58^{\mathrm{cy}} \pm 0.43$ & $10.17^{\mathrm{bx}} \pm 0.51$ & $11.54^{\mathrm{ax}} \pm 0.28$ & $10.08^{\mathrm{bx}} \pm 0.55$ & $4.55^{\mathrm{dy}} \pm 0.28$ & $9.67^{\mathrm{bcx}} \pm 0.43$ \\
\hline \multicolumn{7}{|c|}{ Foaming capacity (\%) } \\
\hline Variety & Raw & Dehusked & Soaked & Autoclaved & Extruded & Germinated \\
\hline G 80 & $49^{\mathrm{cx}} \pm 4.36$ & $63^{\mathrm{ay}} \pm 3.61$ & $50^{\mathrm{bcx}} \pm 3.00$ & $58^{\mathrm{abx}} \pm 2.65$ & $29^{\mathrm{dx}} \pm 2.65$ & $54^{\mathrm{bcy}} \pm 3.06$ \\
\hline Ageta 112 & $52^{\mathrm{cx}} \pm 2.00$ & $84^{\mathrm{ax}} \pm 1.45$ & $34^{\mathrm{dy}} \pm 1.33$ & $58^{\mathrm{bx}} \pm 2.65$ & $14^{\mathrm{ey}} \pm 1.11$ & $54^{\mathrm{cy}} \pm 0.77$ \\
\hline HG 365 & $32^{\mathrm{dy}} \pm 1.76$ & $80^{\mathrm{ax}} \pm 2.27$ & $47^{\mathrm{cx}} \pm 1.48$ & $48^{\mathrm{cy}} \pm 2.21$ & $16^{\mathrm{ey}} \pm 2.43$ & $65^{\mathrm{cx}} \pm 2.13$ \\
\hline \multicolumn{7}{|c|}{ Foam stability (\%) } \\
\hline G 80 & $41.86^{\mathrm{by}} \pm 2.36$ & $43.04^{\text {aby }} \pm 1.82$ & $44.68^{\mathrm{abx}} \pm 3.19$ & $47.89^{\mathrm{ax}} \pm 1.38$ & $15.52^{\mathrm{cx}} \pm 1.94$ & $44.23^{\mathrm{aby}_{ \pm}} \pm 1.18$ \\
\hline Ageta 112 & $50.00^{\mathrm{bx}} \pm 2.44$ & $52.32^{\mathrm{ax}} \pm 1.58$ & $33.87^{\mathrm{cy}} \pm 1.71$ & $37.10^{\mathrm{dy}} \pm 2.31$ & $15.38^{\mathrm{ex}} \pm 2.15$ & $53.89^{\mathrm{ax}} \pm 1.87$ \\
\hline HG 365 & $48.00^{\mathrm{ax}} \pm 2.23$ & $51.76^{\mathrm{ax}} \pm 3.14$ & $42.65^{b x} \pm 2.74$ & $39.06^{\text {by }} \pm 1.47$ & $18.27^{\mathrm{cx}} \pm 1.18$ & $49.54^{\mathrm{ay}} \pm 2.44$ \\
\hline
\end{tabular}

${ }^{*}$ Means of triplicate analysis; ${ }^{* *}$ Means with $\mathrm{x}-\mathrm{z}$ superscripts (column wise) are significantly $(\mathrm{P} \leq 0.05)$ different and superscripts a-d (row wise) shows significant $(\mathrm{P} \leq 0.05)$ effect of processing treatment within a culivar.

Table 3. Pearson's correlation coefficient between various physicochemical and functional properties of flours from guar bean varieties.

\begin{tabular}{ccccccc}
\hline & Treatment & Protein & WAI & WSI & Foaming capacity & Foaming stability \\
\hline Protein & $0.419^{* *}$ & & & & \\
WAI & -0.165 & 0.247 & & & \\
WSI & $0.520^{* *}$ & -0.020 & 0.117 & & \\
Foaming Capacity & $-0.372^{* *}$ & 0.245 & $0.300^{*}$ & $0.414^{* *}$ & \\
Foaming Stability & $-0.315^{*}$ & $0.436^{* *}$ & 0.206 & $0.543^{* *}$ & $0.788^{* *}$ & -0.151 \\
OAC & $0.623^{* *}$ & $0.417^{* *}$ & -0.242 & $-0.531^{* *}$ & -0.262 & \\
\hline
\end{tabular}

$\mathrm{WAI}=$ Water absorption index, WSI $=$ Water solubility index, $\mathrm{OAC}=$ Oil absorption index; $* \mathrm{P} \leq 0.05 .,{ }^{*} \mathrm{P} \leq 0.01$.

different conformational features of the proteins (Andualem and Gessesse, 2013). At higher temperatures, the protein structures breakdown and exposes the non-polar residues of the proteins that improves the binding of glycerrides, thus improves OAC (Nithiyananthama et al., 2013). However, significant reduction in OAC was observed in extruded kidney bean flour by Alonso et al. (2000).

Gelling capacity: Gelling capacity holds significance in food products like soups, sauces, etc. that require thickening and gelling. Gelation may be described as a process in which denatured molecules cross-link to form aggregates stabilized by a variety of bonds including, electrostatic interactions, hydrogen, hydrophobic and/or disulfide bonds. The gelation of proteins is favored by their size, since large molecules form extensive networks by cross-linking in three dimensions (Oakenfull et al., 1997). Dehusking reduced the gel strength of guar bean flour and the results are supported by the recordings of Odedeji et al. (2011). However, autoclaving and germination enhanced the gel strength of guar flour. Maximum gel strength was observed for germinated Ageta 112. Similarly, decrease was noticed on soaking by Prinyawiwatkul et al. (1997) for cowpea flour. Extrusion processing adversely affected the gel strength of flour from varieties of guar, that was possibly due to disruption of the molecular structures at higher temperature and pressure. Gelation mechanism and gel appearance are fundamentally controlled by the balance between attractive hydrophobic interactions and repulsive electrostatic interactions (Egelandsal, 1980).

Pearson's correlation coefficient: Table 3 depicts the correlation between the processing treatments, physicochemical and functional properties of flours from different varieties of guar bean. Processing treatments revealed a significantly positive correlation between protein content, WSI and OAC, however, a negative correlation was observed with foaming capacity and foaming stability. The proteins of guar bean were positively correlated to its foaming stability $(\mathrm{r}=0.436)$ and oil absorption capacity $(\mathrm{r}=0.417)(\mathrm{P} \leq 0.01)$. WAI was positively correlated with foaming capacity $(\mathrm{P} \leq 0.05)$. WSI exhibited a positive correlation with foaming capaci- 
ty and foaming stability and a negative correlation with oil absorption capacity $(\mathrm{P} \leq 0.01)$. Foaming capacity showed a significantly positive correlation $(\mathrm{P} \leq 0.01)$ with foaming stability $(\mathrm{r}=0.788)$ but was negatively correlated to OAC. Similarly, a negative correlation was observed between OAC and Foaming stability $(\mathrm{r}=-0.151)$.

\section{Conclusion}

Germination of seeds significantly increased the protein content, however, slightly decreased the fat content. Ageta 112 showed the highest L* value and were significantly affected by extrusion processing that reduced the lightness value. Functional properties i.e. WAI, WSI, foaming properties, gelling strength were significantly reduced during extrusion processing. However, other processing treatments improved the functional properties of guar flour. Ageta 112 was observed with better functional properties and thus recommended for foods with desirable properties. Positive correlation of processing treatments with protein $(\mathrm{r}$ $-0.419)$, WSI $(r=0.520)$ and $\mathrm{OAC}(\mathrm{r}=0.623)$, were observed whereas, showed a negative correlation with foaming properties. The results of the present study concluded that guar bean, which is an underutilized crop posses the potential to improve the properties of the food products along with its nutritional properties.

\section{REFERENCES}

AACC (2000). Approved methods. American Association of Cereal Chemist, 10th ed. AACC, St. Paul Minnesota, USA.

Adebowale, Y.A., Adeyemi, A. and Oshodi, A. (2005). Variability in the physicochemical, nutritional and antinutritional attributes of six Mucuna species. Food Chem., 89: $37-48$

Alonso, R., Orue, E., Zabalza, M., Grant, G. and Marzo, F. (2000). Effect of extrusion cooking on structure and functional properties of pea and kidney bean proteins. $J$. Sci. Food Agric., 80: 397-403

Andualem, B. and Gessesse, A. (2013). Effect of cooking on protein digestibility, fractions content and functional characteristics of defatted Millettia ferruginea seed flour. World App. Sci. J., 27(9): 1111- 1118

Aguilera, Y., Esteban, R.M., Benitez, V., Molla, E. and Martin-Cabrejas, M.A. (2009). Starch, functional properties, and microstructural characteristics in chickpea and lentil as affected by thermal processing. J Agric. Food Chem., 57(22): 10682- 10688

Brennan, C.S., Blake, D.E., Ellis, P.R. and Schofield, J.D. (1995). Effects of guar galactomannan on wheat bread microstructure and on the in vitro and in vivo digestibility of starch in bread. J. Cereal Sci., 24: 151-160

Egelandsal, B. (1980). Heat induced gelling in solutions of ovalbumin. J. Food Sci., 45: 570-573

El-Adawy, T.A. (2002). Nutritional composition and antinutritional factors of chickpeas (Cicer arietinum L.) undergoing different cooking methods and germination. Plant Food Hum. Nutr., 57: 83-97

Esenwah, C.N. and Ikenebomeh, M.J. (2008). Processing effects on the nutritional and anti- nutritional contents of African locust bean (Parika biglobosa Benth.) seed.
Pak. J. Nutr., 7(2): 214- 217

Fabrenbach, M., Riccardi, B.A., Saunders, J.C., Lourie, I.N. and Heider, J.G. (1965). Comparative effects of guar gum and pectin on human serum cholesterol levels. Circulation, 11: 31-32

Ghavidel, R.A. and Prakash, J. (2006). Effect of germination and dehulling on functional properties of legume flours. J. Sci. Food Agric., 86: 1189- 1195

Joshi, U.N., Arora, S.K. and Arora, R.N. (1990). Differential chemical composition of guar species. Guar Res. Annals, 6: 38-40

Kaur, M., Sandhu, K.S. and Singh, N. (2007). Comparative study of the functional, thermal and pasting properties of flours from different field pea (Pisum sativum L.) and pigeon pea (Cajanus cajan L.) cultivars. Food Chem., $104: 259-267$

Khalil, A.H. and Mansour, E.H. (1995). The effect of cooking, autoclaving and germination on the nutritional quality of faba beans. Food Chem., 54: 177- 182

Khattab, R.Y. and Arntfield, S.D. (2009). Functional properties of raw and processed canola meal. LWT - Food Sci. Technol., 42:1119-1124

Lin, M.J.Y., Humbert, E.S. and Sosulski, F.W. (1974). Certain functional properties of sunflower meal products. $J$. Food Sci., 39(2): 368-370

Ma, Z., Boye, J.I., Simpson, B.K., Prasher, S.O., Monpetit, D. and Malcolmson, L. (2011). Thermal processing effects on the functional properties and microstructure of lentil, chickpea, and pea flours. Food Res. Int., 44: 2534- 2544

Martin-Cabrejas, M., Ariza, N., Esteban, R., Molla, E., Waldron, K. and Lopez-Andreu, F. (2003). Effect of germination on the carbohydrate composition of the dietary fiber of peas (Pisum sativum L.) J. Agri. Food Chem., 51(5): 1254-1259

Mittal, R., Nagi, H.P.S., Sharma, P. and Sharma, S. (2012). Effect of processing on chemical composition and antinutritional factors in chickpea flour. J. Food Sci. Eng., 2: $180-186$

Mubarak, A.E. (2005). Nutritional composition and antinutritional factors of mung bean seeds (Phaseolus aureus) as affected by some home traditional processes. Food Chem., 89: 489- 495

Mugendi, J.B., Njagi, E.N.M., Kuria, E.N., Mwasaru, M.A., Mureithi, J.G. and Apostolides, Z. (2010). Effects of processing technique on the nutritional composition and anti-nutrient content of mucuna bean (Mucuna pruriens L.). Afr. J. Food Sci., 4(4): 156 - 1, 66

Nithiyananthama, S., Siddhurajua, P. and Francis, G. (2013). Proximate composition and functional properties of raw and processed Jatropha curcas L. kernel meal. Int. J. Res. Pharm. Biomed. Sci., 4: 183-195

Oakenfull, D., Pearce, J. and Burley, R.W. (1997). Protein gelation. In Damodaran, S. and Paraf, A. (Eds.), Food proteins and their applications. New York, Marcel Dekker $p p: 111-141$

Odedeji, J.O. and Oyeleke, W.A. (2011). Comparative studies on functional properties of whole and dehulled cowpea seed flour (Vigna unguiculata). Pak. J. Nutr., 10(9): 899-902

Prinyawiwatkul, W., Beuchat, L.R., McWatters, K.H. and Phillips, R.D. (1997). Functional properties of cowpea (vigna unguiculata) flour as affected by soaking, boiling, and fungal fermentation. J. Agric. Food 
Priyanka Sharma et al. / J. Appl. \& Nat. Sci. 8 (4): 2120-2127 (2016)

Chem., 45 (2): 480-486

Rumiyati, James, A.P. and Jayasena, V. (2012) Effect of germination on the nutritional and protein profile of Australian Sweet Lupin (Lupinus angustifolius L.). Food Nutr. Sci., 3: 621- 26

Singh, K., Kheterpaul, N. (2011). Development of potato and guar ben vegetable and raita using fresh guar (Cyamopsis tetragonoloba) pods. J Food Legume., 24: 235- 238

Sirtori, C.R. and Lovati, M.R. (2001). Soy proteins and cardiovascular disease. Corr. Atheroscler. Rep., 3: 47-53
Trugo, L.C., Donangelo, C.M., Trugo, N.M.F. and Knudsen, K.E.B. (2000). Effect of heat treatment on nutritional quality of germinated legume seeds. J. Agri. Food. Chem., 48(6): 2082-2086

Wolf, W. (1970). Soybean proteins. Their functional, chemical, and physical properties. J. Agric. Food Chem., 18 (6): 969-976

Zambrano, F., Despinoy, P., Ormenese, R.C.S.C. and Faria, E.V. (2004) The use of guar and xanthan gums in the production of 'light' low fat cakes. Int. J. Food Sci. Technol., 39: 959- 966 